\title{
Supplier-Customer Relationship Management and Customer Retention: A Perspective on Motor Dealerships in an Emerging Economy
}

\author{
Mornay Roberts-Lombard
}

Department of Marketing Management, University of Johannesburg, RSA

Email: mornayrl@uj.ac.za

\section{Munyaradzi Wellington Nyadzayo}

School of Business, Monash University, Australia

\section{Doi:10.5901/mjss.2014.v5n20p792}

\section{Abstract}

The purpose of the study was to investigate the influence of service quality, customer satisfaction and customer value on customer retention via Customer Relationship Management (CRM) performance at selected motor dealerships in the Buffalo City Municipality of South Africa (hereafter referred to as Buffalo City Municipality). The population included all customers of Toyota, Volkswagen and Nissan dealership brands in the Buffalo City Municipality. Both stratified random sampling and simple random sampling were used and a total of 252 customers participated in the study. Primary data was gathered using a selfadministered questionnaire. Data was analysed using Structured Equation Modelling (SEM). The findings stipulate that the application of CRM is fundamental to obtaining the desired results of retaining more customers, in addition to obtaining more profitable customers and using the existing customers as advocates for acquiring new customers and spreading the positive word of the motor dealership outlet. The managers of motor dealerships must therefore understand that managing customer retention in isolation will not generate maximum revenues.

Keywords: Service quality, customer satisfaction, customer value, Customer Relationship Management (CRM), motor dealerships

\section{Introduction}

To survive in the current, competitive business environment and to secure a competitive advantage, businesses are required to pay significant attention to customer service and business - customer relationship quality. This requires an adjustment in the marketing orientation of a business from product based to that of customer centred. While the ability to understand and satisfy the needs of a customer is identified as key to achieve associated business goals, more efforts in the current marketplace have been directed to develop and maintain the quality of business - customer relationships with an objective to retain customers (Negi and Katema, 2010:1).

Excellent service delivery, increased customer satisfaction, value and loyalty have been found to positively influence long-term financial performance of businesses because customer attrition is low. Additionally, it is important to note that the profitability of motor dealerships depends particularly on their ability to motivate existing customers to increase their service usage and purchase additional products or services (Balas and Tareef, 2011:61). To achieve this, relationship managers must strive to convert transactional interactions into long-term collaborative partnerships through effective Customer Relationship Management (CRM). CRM has directed the attention towards various vital aspects, including the necessity of a direct relationship between customers and marketers, the importance of keeping current customers, as well as the inevitability of building long-term relationships with customers instead of the customer-oriented transaction method in order to augment the profitability of the business (Sanzo and Vasquez, 2011:55-56). Shamdasani et al. (2008:118-119) further state that CRM seeks to understand and influence customer behaviours through meaningful and mutual communication with customers to improve customer acquisition, retention, loyalty, value and profitability over time.

The motor industry is crucial to South Africa in terms of Gross Domestic Product (GDP) and employment. Overall, the automotive industry, including manufacturing, distributing and servicing of vehicles and components is the third largest sector in the South African economy after mining and financial services, contributing approximately seven per cent to GDP (South Africa Info, 2012). However, in such a competitive environment, consumers today are complicated and 
have more choices for their financial needs than ever before. This is due to technology, globalisation, increased competition and increased consumer mobility, all which have dramatically changed the manner in which people seek information and purchase services and products (Nargundkar, 2006:358). For example, in 2011, South African consumers could choose between approximately 1390 variants of cars from 50 different brand names (South Africa Info, 2012). Hence, the focus of businesses are now increasingly on appropriate, well researched and even aggressive marketing to ensure the survival of the business in the face of such fierce competition (Amoako, 2012:136). Consequently, motor dealerships in South Africa must be able to follow suit and emphasise the significance of customercentred philosophies and quality management approaches to enhance their competitive advantage. Furthermore, in today's era of intense competition for acquiring and retaining customers, customer retention can become a major issue and a key objective in the motor industry. This is mainly due to the large growing number of motor dealerships which are targeting almost the same cohort of customers, and are equipped with similar levels of technological competencies. Therefore, in the modern marketing era which is highly customer-centric, prioritising customer metrics such as service quality, customer loyalty and customer value is a strategic weapon in attracting and retaining existing customers (Trasorras et al., 2009:616-617).

This article provides an explanation of the research problem that was investigated and the research objectives, hypotheses and methodology that were followed. Thereafter, the empirical results are discussed followed by management implications and recommendations.

\section{Literature Review}

\subsection{The Customer Value Chain}

Donaldson et al. (2006:175) argue that the customer chain is a visual mapping design tool that is used when initiating the process of product development. This will empower design teams to specify key customers and their relationships to the product or process being designed (Crain and Abraham, 2008:33-34). According to Walker, Johnson and Leonard (2006:25), the customer value chain is initiated when the customer makes the decision to buy a new vehicle, continues through the purchase and ownership experience, and concludes with the re-buying phase where the cycle starts all over again. Customers who purchase a specific brand of motor vehicle and who are then satisfied throughout the value chain, contribute to the success of the motor dealership in several ways. These customers contribute to the maintenance and repair business of the dealership, they purchase accessories from the dealership, and eventually decide to purchase another vehicle from the same branded dealership. Furthermore, these customers bring new customers to the dealership with the intention of making the dealership part of the new customers' value chain (Balas and Tareef, 2011:60). An effective and efficient supply function management will allow the products to meet the standards required by the production department and by customers. Increased competition demands that organisations respond to customers' changing needs in uncertain environments. Relationship-specific adaptations can be used by organisations to address customer needs more accurately by investing in products, processes or procedures that will meet the specific needs of an exchange partner. An example being the tailoring of marketing systems or customising products to meet customer needs. These specific improvements may enhance channel efficiency and provide improved functionality for the customer (Hsieh et al., 2008:381).

\subsection{Antecedents of CRM}

\section{Service Quality}

Service quality is being increasingly perceived as a tool to increase the value for the customer, and serves as a means of positioning in a competitive environment to ensure customer satisfaction, retention and patronage (Kaul, 2007:15). High levels of service quality may lead to increased customer retention, higher profitability, increased market share and lower employee turnover. This confirms that customers are more satisfied with the business and suggests that they have positive perceptions of the business and view their relationship as satisfying (Kuo et al., 2009:889). When purchasing goods, the customer attempts to attach a number of tangible cues in order to evaluate quality (Hu, et al., 2009:112). On a motor vehicle, a customer would thus consider the colour, style, shape, label and interior feel of the vehicle. On the other hand, when purchasing services, fewer tangible cues exist. In most cases, tangible evidence is limited to the service provider's physical facilities, equipment and employees (Botha and Van Rensburg, 2010:47). In addition, service quality perceptions result from a comparison of consumer expectations with actual service performance. A number of service 
quality definitions acknowledge in harmony that service quality entails conforming to customer expectations which are enacted when they perceive to be receiving a certain level of service (Amoako, 2012:135).

\section{Customer Satisfaction}

The ultimate aim of any business is to ensure that the customer who buys its product or service is satisfied. Customer satisfaction can be described as the degree to which a business's product or service performance matches up to the expectations of the customer (Kotler and Armstrong, 2005:17). When purchasing products or services, customers bear certain levels of expectations and they know how they will feel or react after using or experiencing the service (Akbar et al., 2010:115). It is crucial to note that whether or not the customers' expectations have been met, solely rests on the individual's perceptions. For instance, when a customer purchases a car or has his/her car serviced with a certain dealership, he/she would expect it to work properly. If it does not, the customer is dissatisfied and if it does, the customer is satisfied. In such circumstances, it is therefore the responsibility of the business to strategically determine ways of resolving the problem in order to ensure the customer is satisfied (i.e. the problem that may arise is resolved according to the customer's approval) (Tsai et al., 2010:130). Motor dealerships must know that satisfied customers are more likely to come back for additional purchases and recommend the business to their community using word-of-mouth. In addition, they are less likely to turn to competitors, since they will be happy and would want to stay in the relationship which in turn increases the profitability of the business (Eshghi et al., 2007: 95). Therefore, a business must prioritise regarding the provision of continuous levels of high quality service that could lead to customer satisfaction, which is a crucial factor in creating customer loyalty (Helkkula and Kelleher, 2010:38).

\section{Customer Value}

Customer value is viewed as a strategic tool to secure the attraction and retention of customers. An inherent driving force of CRM performance is the delivery of superior customer value. Therefore, if businesses want to improve on their CRM performance, they will have to adapt their activities to ensure the creation and optimal delivery of superior customer value (Wang et al., 2008:169). Businesses must move away from extracting their profits from single transactions to maximising revenue over a series of transactions. By offering consumers greater value, either through lower prices or by providing more benefits that justify higher prices, a business can gain a competitive advantage over its competitors. In addition, superior customer value has been associated with customer satisfaction and satisfied customers are more likely to repurchase the products/services of a business (Helkkula and Kelleher, 2010:39). Vantrappen (1992:54) stated that "... value creation for the customer implies that the business meets the customer's quality, delivery and cost expectations." Therefore, businesses that provide superior customer value are able to build customer retention. Customer value is created when the customer perceives that the benefit of consuming products/services exceeds sacrifices (Angelis et al., 2010:7). Therefore, it can be argued that if the customer perceives that the product/service benefits exceed sacrifices, value is created and the probability that the customer will repurchase the product/service is high (Baran et al., 2008:112).

\subsection{Customer retention}

The concept of customer retention is central to Customer Relationship Management (Ngai et al., 2008:4). In today's competitive business world it is beneficial for businesses to retain their already existing customers. Customer retention, customer loyalty and customer satisfaction are positively related concepts in assisting the profitability of the business, and they are some of the driving forces behind Customer Relationship Management. It is less expensive to cultivate your existing customer base and sell more services to them, than to seek new single-transaction customers. Customer retention affects both revenues and cost in the equation of profitability. Revenues are enhanced due to increased sales, and costs are lowered due to lesser generation and marketing costs of such revenues (Coyles and Gokey, 2005:103).

From the background, problem statement and literature discussion it can be concluded that the relationship between service quality, customer satisfaction, customer value and customer retention needs to be investigated as these relationships have remained unexplored. Figure1 reflects the hypohesis and the relationship between the independent variable, the intervening variable and the dependent variable. These relationships are important as they can lead to increased customer loyalty for the organisation. 
Figure 1: Proposed conceptual framework

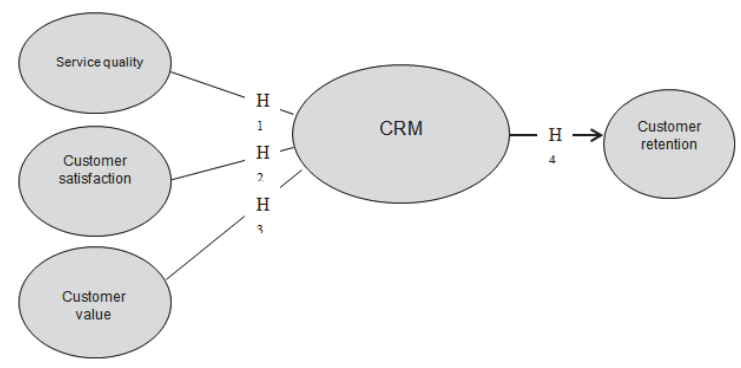

Source: Researcher's own construct

\section{Rationale for the Study and Methodology Employed}

The 21st century customer is now exposed to numerous vehicle suppliers, mainly due to their access to technologicallyimproved marketing communication and the continuously expanding global market (globalisation). However, losing an individual customer due to such a competitive environment, will impact negatively on the profitability of motor dealerships. Consequently, if motor dealerships prioritise the provision of excellent services, it will significantly improve their profitability in terms of the individual customer's lifetime value due to improved customer retention. The article will focus on the importance for motor dealerships to better understand the need for CRM, and how that will lead to customer retention. The modern customer is faced with an array of automotive services and expects customised offerings, customer value, ease of access, service and repairs, and other related issues from their service providers. These market forces lead to a strategic imperative, namely a customer-focused strategy. The problem statement therefore is that the the influence of service quality, customer satisfaction, and customer value on customer retention through the mediating influence of Customer Relationship Management (CRM) at motor dealerships in the Buffalo City Municipality remains unclear and unexplored. In line with the problem statement presented, the primary objective of this study was to investigate the influence of service quality, customer satisfaction, and customer value through CRM performance as the mediating variable on motor dealerships in the Buffalo City Municipality. Forthcoming thus from literature, the following hypotheses have been formulated:

H1: CRM performance strongly mediates the effect of service quality on customer retention for motor dealerships in the Buffalo City Municipality.

H2: CRM performance strongly mediates the effect of customer satisfaction on customer retention for motor dealerships in the Buffalo City Municipality.

H3: CRM performance strongly mediates the effect of customer value on customer retention for motor dealerships in the Buffalo City Municipality.

H4: CRM performance positively influences customer retention for motor vehicle dealerships in the Buffalo City Municipality.

The population elements included customers of Toyota, Nissan and Volkswagen dealership brands in the Buffalo City Municipality. Since the elements of this study are customers, the researcher made use of the motor dealerships' customer databases. The customers should have used the services of any of the motor dealerships under study and should understand the concept being measured. The sampling techniques used in this study included stratified random sampling and simple random sampling. A probability sampling approach was followed, mainly because the procedure is objective in that the probability of selection will be known in advance for each population unit (Parasuraman et al., 2007:169). Thus, the researcher played no role in determining which specific population units should form part of the sample. As a result, the stratified random sampling technique was used to select the respondents. In this study, the two main strata were grouped and divided in terms of location, that is, East London and King William's Town customers. Secondly, substrata were formulated according to the dealership brand name, that is, Toyota, Nissan and Volkswagen. After segmenting the population elements into exclusive groups, elements were then selected from each stratum through a simple random sampling approach. A total of 252 questionnaires were completed.

A quantitative research design was used for this research study. Self-administered questionnaires were used to collect the data. The questionnaire used for the study comprised of Likert scale statements. The questions were weighed 
on a 7-point scale where the respondent was given a continuum of labelled categories that represents the range of responses varying from $1=$ strongly disagree to $7=$ strongly agree. Questionnaires were personally distributed to respondents visiting the motor dealership's site. Before the main fieldwork, the questionnaire was pre-tested amongst 15 respondents. These respondents were from the target population located in both East London and King William's Town, since it is advised to use similar respondents to those who will be included in the survey (Malhotra, 2009:520). Structural equation modeling (SEM) was used to measure the relationships between the independent variables and dependent variables simultaneously in order to test the theoretical model of this study (see Figure 1). SEM was the most appropriate analysis method as it produces comprehensive overall goodness-of-fit. In other words, through a confirmatory approach, the theoretical model of this study was tested using SEM to determine if the pattern of variances and co-variances in the data was consistent with the structural or path model specified in the study. In addition, SEM enabled the accommodation of measurement errors and incorporated abstract and unobservable constructs. Finally, SEM helped accommodate and test multiple interrelated dependence relationships in a single model which could not be done by other multivariable techniques (Hair et al., 2006:712). The SEM in this study was performed using Analysis of Moment Structures (AMOS) version 17. AMOS was also used to calculate the Cronbach alpha coefficient values, conduct a Confirmatory Factor Analysis (CFA) and a One-Way Analysis of Variances (ANOVA).

\section{Findings and Discussion}

\subsection{Reliability testing and results discussion}

According to Fornell and Larcker (1981:46) and Joreskog (1971:110), Cronbach alpha values can be calculated using the two formulas that follow, as well as the use of standardised regression weights computed through the AMOS software.

Equation 1: Construct reliability (CR) Equation 2: Variance extracted (VE)

$$
\mathbf{C R}=\frac{\left(\sum_{i=1}^{p} \lambda i\right)^{2}}{\left(\sum_{i=1}^{p} \lambda i\right)^{2}+\sum_{i=1}^{p}\left(1-\lambda_{i}^{2}\right)}
$$$$
\mathbf{V E}=\frac{\sum_{i=1}^{p} \lambda i^{2}}{\sum_{i=1}^{p} \lambda i^{2}+\sum_{i=1}^{p}\left(1-\lambda i^{2}\right)}
$$

Where:

$\lambda$ : the $i$ th standardised factor loadings on its corresponding factor;

1- $\lambda i$ 2: the variance of measurement error of each indicator; and

$\mathrm{P}$ : the number of indicators.

Construct reliability should be 0.7 or higher to indicate adequate convergence or internal consistency. The amount of variance extracted should be greater than 0.50 to ensure the validity of the scale under investigation (Fornell and Larcker, 1981:46). Table 1 provides evidence of convergence with all construct reliability estimates above 0.70 . Similarly, all the numbers of average variance extracted estimates are well above the 0.50 cut-off, indicating significant convergent validity on the constructs.

Table 1: Construct reliability

\begin{tabular}{|l|c|c|}
\hline Construct & Cronbach Alpha value & Average variance extracted $^{*}$ \\
\hline Service quality* & 0.94 & 0.85 \\
\hline CRM performance* & 0.91 & 0.87 \\
\hline Customer satisfaction & 0.92 & 0.84 \\
\hline Customer value & 0.87 & 0.80 \\
\hline Customer retention & 0.87 & 0.83 \\
\hline
\end{tabular}

*Summated scales

The structural model of the mediating effects showed evidence of acceptable model fit based on the assessment of the overall fit statistics illustrated in Table 2, which shows that the model significantly fits to the data. This has been assessed through the Cmin/df value of 2.73 which is below 3 , GFI of 0.82 (close to 0.9 ), AGFI of 0.80 , as well as the RMSEA estimate of 0.088 which satisfies the threshold of 0.08 (Hair et al., 2006:779). Moreover, all the model comparison indices (TLI, CFI and TLI) satisfy the threshold estimate of 0.90 , which indicates a good model fit. Having satisfied both the stages of structural equation modeling (that is, testing the fit and validity of both the measurement and structural models), 
it was then necessary to proceed with testing the hypothesised relationships. For the purposes of this study, construct validity was first examined for the measurement model and the same procedure was then done for the integrated structural model. Only the results of the integrated structural model are provided. This is illustrated by Figure 2.

Table 2: Goodness-of-fit results for the structural model

\begin{tabular}{|c|c|c|c|}
\hline Goodness-of-fit measure & Result & Goodness-of-fit measure & Result \\
\hline \multicolumn{2}{|l|}{ Model fit } & \multicolumn{2}{|c|}{ Model comparison } \\
\hline$\chi^{2}$ & 603.307 & Tucker-Lewis Index (TLI) & 0.912 \\
\hline Degrees of freedom & 221 & Normed Fit Index (NFI) & 0.885 \\
\hline$p$-value & .000 & \multirow{5}{*}{ Comparative Fit Index (CFI) } & \multirow{5}{*}{0.923} \\
\hline Cmin/df & 2.730 & & \\
\hline Goodness-of-fit Index (GFI) & 0.816 & & \\
\hline Adjusted GFI (AGFI) & 0.770 & & \\
\hline RMSEA & 0.088 & & \\
\hline
\end{tabular}

Figure 2: Integrated structural model: Mediating effectsof CRM performance

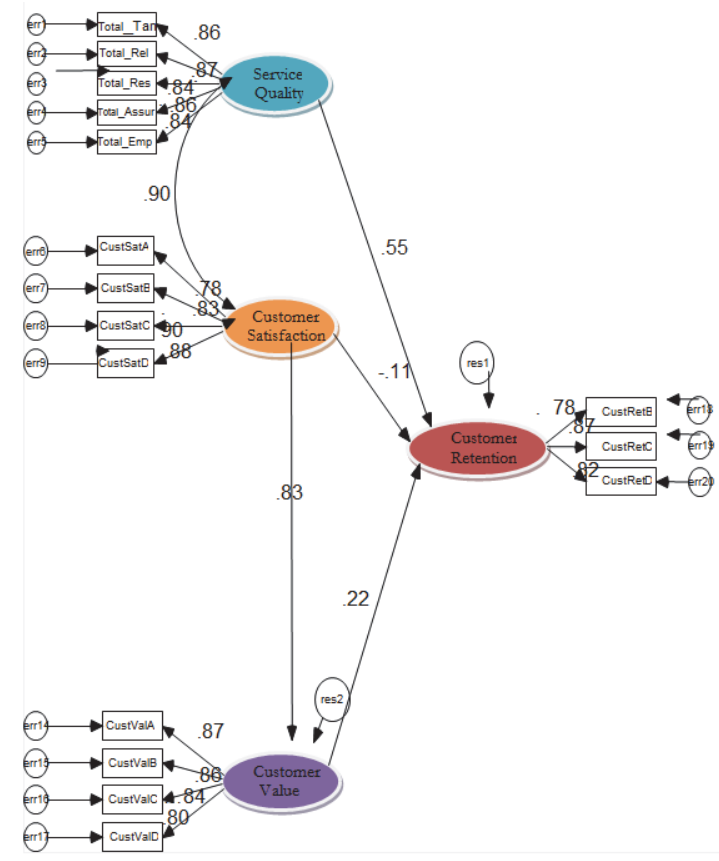

Source: Researcher's own construct

\subsection{Hypothesis testing: The mediating effects of CRM performance}

The results of the hypotheses testing are illustrated by Table 3. 
Table 3: Hypothesis testing based on the structural model of mediating effects

\begin{tabular}{|c|c|c|c|c|c|c|c|}
\hline \multirow{2}{*}{$\begin{array}{l}\text { Hypothesis } \\
\text { H1 }\end{array}$} & \multicolumn{3}{|l|}{ Correlation between variables } & \multirow{2}{*}{$\begin{array}{l}\text { Estimate } \\
.541\end{array}$} & \multirow{2}{*}{$\begin{array}{l}\text { S.E. } \\
.111\end{array}$} & \multirow{2}{*}{$\begin{array}{l}\text { C.R. } \\
4.868\end{array}$} & \multirow{2}{*}{$\begin{array}{l}\text { P-value } \\
.000\end{array}$} \\
\hline & 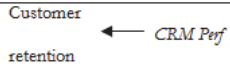 & $\longleftarrow$ & Service Quality & & & & \\
\hline H2 & $\begin{array}{l}\text { Customer } \\
\text { retention }\end{array}$ & $\longleftarrow$ & $\begin{array}{l}\text { Customer } \\
\text { Satisfaction }\end{array}$ & -119 & .104 & -1.145 & 0.252 \\
\hline $\mathrm{H}_{3}$ & 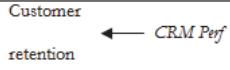 & $\longleftarrow$ & Customer Value & .386 & .086 & 4.508 & $0.000 * 0 *$ \\
\hline $\mathrm{H}_{4}$ & Customer retention & & $\begin{array}{l}\text { CRM } \\
\text { Performance }\end{array}$ & .884 & .070 & 12.657 & $0.000 * 0 \times$ \\
\hline & Customer loyalty & & $\begin{array}{l}\text { Customer } \\
\text { Satisfaction }\end{array}$ & .700 & .050 & 13.970 & $0.000^{* \infty \neq}$ \\
\hline
\end{tabular}

${ }^{*} p<0.1,{ }^{* *} p<0.05,{ }^{* * *} p<0.001$

SE: standard error, CR: critical ratio, Estimate: standard regression weight, CRM perf: Customer Relationship Management performance. Note: Highlighted section indicates a post hoc analysis that was important to explain the insignificant result of $\mathrm{H} 2$.

Hypothesis 1: CRM performance strongly mediates the effect of service quality on customer retention for motor dealerships in the Buffalo City Municipality.

The structural equation modeling results in Table 3 indicate that the standardised regression weight estimate of the mediating effect of CRM performance on the structural path between service quality and customer retention was positive at 0.541 and strongly significant ( $S E=0.111, p=0.000$ ). In other words, one unit increase in CRM performance will result in a 54.1 per cent increase in the influence of service quality on customer retention. This indicates that hypothesis 1 is supported by the data and it can be concluded that $\mathrm{H} 1$ is accepted and the null hypothesis ( $\mathrm{H} 10)$ which states that "CRM performance insignificantly mediates the effect of service quality on customer retention for motor dealerships in the Buffalo City Municipality", is rejected.

Hypothesis 2: CRM performance strongly mediates the effect of customer satisfaction on customer retention at selected motor dealerships in the Buffalo City Municipality

The structural equation modeling results indicate in Table 3 that the mediating effect of CRM performance on the structural path between customer satisfaction and customer retention was negative at -0.119 and insignificant (SE = $0.104, p=0.252$ ). In other words, one unit increase in CRM performance will result in a negative influence of customer satisfaction on customer retention by 11.9 per cent. This indicates that hypothesis 2 is not supported by the data, and it can be concluded that $\mathrm{H} 2$ is rejected and the null hypothesis $(\mathrm{H} 20)$ stating that "CRM performance insignificantly mediates the effect of customer satisfaction quality on customer retention", is accepted. A possible explanation to this relationship can be inferred from the positive and significant relationship between customer satisfaction and customer loyalty $(E=0.70, S E=0.05, p=0.000)$.

Hypothesis 3: CRM performance strongly mediates the effect of customer value on customer retention at selected motor dealerships in the Buffalo City Municipality.

The SEM results in Table 3 indicate that the standardised regression weight of the mediating effect of CRM performance on the relationship between customer value and customer retention was positive at 0.386 and strongly significant (SE $=0.086, p=0.000$ ). In other words, a unit increase in CRM performance enhances the influence of customer value on customer retention positively by almost 39 percentage points. This indicates that hypothesis 3 is supported by the data and it can be concluded that $\mathrm{H} 3$ is accepted, but the null hypothesis (H30) which states that "CRM performance insignificantly mediates the effect of customer value on customer retention for motor dealerships in the Buffalo City Municipality", is rejected.

Hypothesis 4: CRM performance positively influences customer retention at selected motor dealerships in the Buffalo City Municipality.

The mediating effects of CRM performance reported on $\mathrm{H} 1, \mathrm{H} 2$, and $\mathrm{H} 3$ are known as partial mediation. However, the final hypothesis examined the composite or total mediating effects of CRM performance between all independent variables (service quality, customer satisfaction, and customer value) and the dependent variable - customer retention, 
known as full mediation. As illustrated in Table 3, the results of SEM show a highly positive standardised regression weight of 0.886 and a strongly significant relationship (SE $=0.07, p=0.0000$ ), indicating that hypothesis 4 is fully supported by the data. That is, one unit increase in CRM performance results in approximately 90 per cent increase in customer retention for motor vehicle dealerships in the Buffalo City Municipality. Hence, it can be stipulated that hypothesis 4 is supported by the data and it can be concluded that $\mathrm{H} 4$ is accepted. Therefore, the null hypothesis ( $\mathrm{H} 40$ ) stating that "CRM performance has an insignificant influence on customer retention for motor vehicle dealerships in the Buffalo City Municipality", is rejected.

\subsection{Summary of the results of the hypotheses testing}

The summary of the results of the hypotheses testing as discussed, overall exhibits that the conceptual framework proposed in Figure 1 was significantly supported by the data, except for hypothesis $2\left(\mathrm{H}_{2}\right)$ as illustrated in Table 4 and Figure 3.

Table 4: Summary of the results of hypotheses testing

\begin{tabular}{|c|l|c|c|}
\hline Hypothesis & \multicolumn{1}{|c|}{ Statement } & p-value & Results \\
\hline $\mathrm{H}_{1}$ & $\begin{array}{l}\text { CRM performance strongly mediates the effect of service quality on customer retention for motor } \\
\text { dealerships in the Buffalo City Municipality }\end{array}$ & $.000^{\star * \star}$ & Supported \\
\hline $\mathrm{H}_{2}$ & $\begin{array}{l}\text { CRM performance strongly mediates the effect of customer satisfaction on customer retention at } \\
\text { selected motor dealerships in the Buffalo City Municipality }\end{array}$ & 0.252 & $\begin{array}{c}\text { Not } \\
\text { supported }\end{array}$ \\
\hline $\mathrm{H}_{3}$ & $\begin{array}{l}\text { CRM performance strongly mediates the effect of customer value on customer retention at } \\
\text { selected motor dealerships in the Buffalo City Municipality }\end{array}$ & $0.000^{\star * \star}$ & Supported \\
\hline $\mathrm{H}_{4}$ & $\begin{array}{l}\text { CRM performance positively influences customer retention at selected motor dealerships in the } \\
\text { Buffalo City Municipality }\end{array}$ & $0.000^{\star * \star}$ & Supported \\
\hline
\end{tabular}

${ }^{*} p<0.1,{ }^{* *} p<0.05,{ }^{* * *} p<0.001$

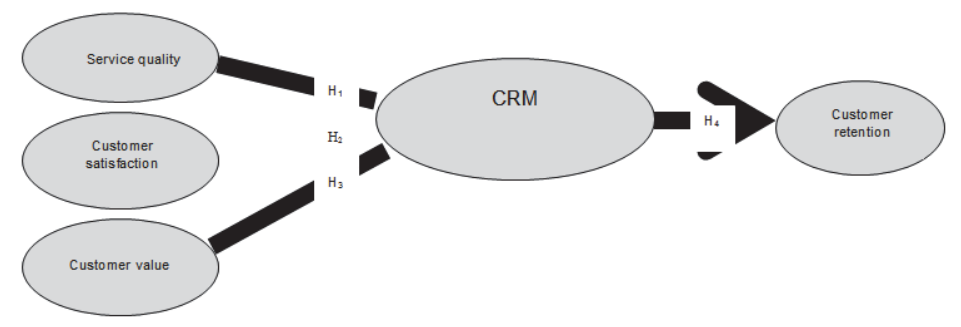

Figure 3: Final model for customer retention at motor dealerships in the Buffalo City Municipality

\section{Managerial Implications and Recommendations}

An important implication evident from this study to managers is the need to control misalignments in the satisfactionretention relationship. Marketers must realise that customers are not similar, and cannot be satisfied at the same levels; some are just satisfied, while some can be completely satisfied (delighted) (Wahab and Ali, 2009:123). This enables relationship managers to understand the effects of customer satisfaction on retention beyond inherent differences in customers' propensities to churn. Similarly, not only are some customers predisposed to stay or to churn, but they are also sensitive to changes in customer satisfaction (Clancy, 2010:10). The efforts of managers might be rewarded through a careful identification of which customers are prone to stay with a provider and likely to respond to satisfaction improvement efforts. This implies that there is a need to understand that satisfaction alone has low impact on customer retention, therefore focus should also be extended to other exogenous factors (e.g. customer value) which affect both attitudinal and behavioural components.

Another strategy available for motor dealership managers is the provision of tailor-made products with individual modifications, such as highly individualised auxiliary services, which are also important to reduce customer defection. Thus, relationship quality also impedes motor dealership management to recognise the individuality of its customers. Managers' efforts might be rewarded through a careful identification of which customers are prone to stay with a provider 
and likely to respond to satisfaction improvement efforts. In addition, the service management in motor dealerships should be aware that competition increases customers' propensity to seek and investigate a variety of services or product offerings. Hence, in their customer retention efforts, they should pay more attention to the different approaches that will lower the variety-seeking syndrome, and this can be achieved by increasing their one-on-one interactions with customers.

Finally, managing customer retention in isolation will not generate maximum revenues, margins and profits. In other words, the profitability of motor dealerships depends particularly on their ability to get existing customers to increase their service usage and purchase additional products and/or services (cross-buying). In order to accomplish this, management must strive to convert transactional interactions into long-term collaborative partnerships through CRM activities. Thus, trust, commitment and relationship satisfaction are important value drivers for customer retention among motor dealerships in the South African motor industry. Motor dealerships should therefore be aware that by reinforcing the continuity of relationships as revealed by trust, commitment and relationship satisfaction (performance measures of CRM), service quality, customer satisfaction, and customer value can have a significant impact on repurchase intentions and profit maximisation in the long run.

\section{Research Limitations and Areas for Future Research}

Firstly, the study was conducted only in selected dealerships, namely Toyota, Nissan and Volkswagen in the Buffalo City Municipality, which cannot be regarded as representative of other motor dealerships in South Africa. More diversified samples of motor dealership outlets other than the three used in the study can provide a follow-up opportunity. Replication studies of this research into other regions of South Africa are also recommended. Finally, new variables or constructs may be necessary to identify diverse ways of thinking about relationship management strategies and customer retention. Thus, attention should also be given to service measures that examine the future orientations of customers. This includes service evaluation metrics such as expected future use, intent to switch, resistance to change, sacrifice and anticipated regret.

\section{Concluding Remarks}

The major aim of this study was to empirically investigate the influence of service quality, customer satisfaction, and customer value on customer retention via CRM performance as the mediating variable focusing on motor vehicle dealerships in the South African motor industry. Based on the empirical findings, the normative model of mediating effects was found significant (except for the customer satisfaction - customer retention link), and the relative influence of CRM performance as a mediating variable on customer retention was found to be strongly significant. This analysis concluded and proposed a model that postulated that customer evaluation metrics have the greatest influence on customer retention, indirectly through CRM performance, for motor dealerships in the Buffalo City Municipality. In essence, motor dealerships should be aware that reinforcing the continuity of relationships as revealed by trust, commitment and relationship satisfaction (performance measures of CRM), service quality, customer satisfaction and customer value can have a significant impact on repurchase intentions and profit maximisation in the long run.

\section{References}

Akbar S, Som APM, Wadood F and Alzaidiyeen NJ (2010). Revitalization of service quality to gain customer satisfaction and loyalty. International Journal of Business \& Management, 5 (6): 113-122.

Amoako GK (2012). Improving Customer Service in the Banking Industry - Case of Ghana Commercial Bank (GCB) - Ghana. International Business Research, 5(4):134-148.

Angelis J, Pinheiro de Lima E and Siraliova J (2010). Servitised experiences: business and management implications. Verslo Aktualijos/Current Issues of Business, 5: 5-21.

Balas A and Tareef F (2011). Implementing Customer focused Service Concept in Auto Workshops in Israel. International Conference - Marketing - from information to decision. Volume 4: 59-71.

Baran RJ, Galka RJ and Strunk DP (2008). Principles of customer relationship management. Mason, Texas: Thomson South-Western.

Botha GJ and Van Rensburg AC (2010). Proposed business process improvement model with integrated customer experience management. South African Journal of Industrial Engineering, 2(1): 45-57.

Clancy R (2010). Do you hear your customers? Do they hear you? American Banker, 175(141): 10-10.

Coyles S and Gokey TC (2005). Customer retention is not enough, Journal of Consumer Marketing, 22(2): 101-105.

Crain DW and Abraham S (2008). Using value-chain analysis to discover customers' strategic needs. Strategy \& Leadership, 36(4):2936. 
Donaldson KM, Ishii K and Sheppard SH (2006). Customer Value Chain Analysis. Research in Engineering Design. 16:174-183.

Eshghi A, Haughton D and Topi H (2007). Determinants of customer loyalty in the wireless telecommunications industry. Telecommunications Policy, 31: 93-106.

Fornell C and Larcker DF (1981). Evaluating Structural Equations Models with Unobservable Variables and Measurement Error. Journal of Marketing Research, 18: 39-50.

Hair JF, Anderson RE, Tatham RL and Black WC (2006). Multivariable data analysis reading (6th Ed.). Upper Saddle River, NJ: Prentice Hall International.

Helkkula A and Kelleher C (2010). Circularity of customer service experience and customer perceived value. Journal of Customer Behaviour, 9(1): 37-53.

$\mathrm{Hu} \mathrm{H}$, Kandampully J and Juwaheer TD (2009). Relationships and impacts of service quality, perceived value, customer satisfaction, and image: An empirical study. Service Industries Journal, 29(2):111-125.

Hsieh YC, Chiu HC and Hsu YC (2008). Supplier market orientation and accommodation of the customer in different relationship phases. Industrial Marketing Management, 37:380-393.

Joreskog GK (1971). Statistic Analysis of sets of Congeneric tests. Psychometrica, 36(2): 109-133.

Kaul S (2007). Measuring Retail Service Quality: Examining Applicability of International Research Perspectives in India. Journal of Decision Makers, 32(1): 15-26.

Kotler P and Armstrong G (2005). Principles of Marketing 11th ed. Englewood Cliffs, NJ: Prentice Hall.

Kuo Y-F, Wu C-M and Deng W-J (2009). The relationships among service quality, perceived value, customer satisfaction, and postpurchase intention in mobile value-added services. Computers in Human Behavior, 25: 887-896.

Malhotra NK (2009). Basic Marketing Research - A Decision-Making Approach, (3rd Ed.) Upper Saddle River, New Jersey: Pearson Education.

Nargundkar R (2006). Services Marketing - Text and Cases, (2nd Ed.). New Delhi:

McGraw-Hill.

Ngai EWT, Xiu L and Chau DCK (2008). Application of data mining techniques in customer relationship management: A literature review and classification. Expert Systems with Applications, 10(16): 2-10.

Negi R and Katema E (2010). Relationship Marketing and Customer Loyalty: The Ethiopian Mobile Communications perspective. International Journal of Marketing Management (IJMM), 5(10):113-124.

Parasuraman A, Grewal D and Krishnan R (2007). Marketing Research, (2nd Ed.) New Jersey: Houghton Mifflin Company.

Sanzo MJ and Vasquez R (2011). The Influence of Customer Relationship Marketing Strategies on Supply Chain Relationships: The Moderating Effects of Environmental Uncertainty and Competitive Rivalry. Journal of Business-to-Business Marketing, Volume 18:50-82.

Shamdasani P, Mukherjee A and Malhotra N (2008). Antecedents and consequences of service quality in consumer evaluation of selfservice internet technologies, The Service Industries Journal, 28(1): 117-138.

South Africa Info 2012. South Africa's automotive industry. Available from: http://www.southafrica.info/business/economy/sectors lautomotive-overview.htm (Accessed 09 January 2011).

Trasorras R, Weinstein A and Abratt R (2009). Value, satisfaction, loyalty and retention in professional services. Marketing Intelligence and Planning, 27(5): 615-632.

Tsai M-T, Tsai C-L and Chang H-C (2010). The effect of customer value, customer satisfaction, and switching costs on customer loyalty: An empirical study of hypermarkets in Taiwan. Social Behavior and Personality Journal, 38(6): 729-740.

Vantrappen H (1992). Creating customer value by streamlining business processes, Long Range Planning, 25(1): 53-62.

Wahab S and Ali J (2009). Relationship between Customer Relationship Management Performance and E-Banking Adoption: A Look at Malaysian Banking Industry, International Journal of Business and Management, 4(12): 122-124.

Wang Y, Lo HP, Chi R and Yang Y (2008). An integrated framework for customer value and customer-relationship-management performance: A customer-based perspective from China, Managing Service Quality, 14(2/3): 169-182.

Walker, RH, Johnson, LW and Leonard, S (2006). Re-thinking the conceptualisation of customer value and service quality within the service-profit chain. Managing Service Quality, 16(1):23-36. 